\title{
Expression levels are not as they appear
}

DOI:

10.1038/nrc2201

\section{URLs}

$\mathrm{ER} \alpha$

http://www.ncbi.nlm.nih.gov/ sites/entrez?Db=gene\&Cmd= ShowDetailView\&TermToSearc $\mathrm{h}=2099$ \&ordinalpos $=2$ \&itool $=$ ntrezSystem2.PEntrez.Gene. Gene_ResultsPanel.Gene_ RVDocSum

SRC

http://www.ncbi.nlm.nih.gov/ sites/entrez? Db=gene\&Cmd = ShowDetailViewยTermToSearc $\mathrm{h}=6714$ \&ordinalpos $=1$ \&itool=E ntrezSystem2.PEntrez.Gene. Gene_ResultsPanel.Gene RVDocSum

TFF1

http://www.ncbi.nlm.nih.gov/ sites/entrez? Db=gene\&Cmd= ShowDetailView\&TermToSearc $\mathrm{h}=7031$ \&ordinalpos $=1$ \&itool=E ntrezSystem2.PEntrez.Gene. Gene_ResultsPanel.Gene RVDocSum

\section{GREB1}

http://www.ncbi.nlm.nih.gov/ sites/entrez?Db=gene\&Cmd= ShowDetailView\&TermToSearc $\mathrm{h}=9687$ \&ordinalpos $=1$ \&itool $=\mathrm{E}$ ntrezSystem2.PEntrez.Gene. Gene ResultsPanel.Gene RVDocSum

\section{Breast cancer}

http://www.cancer.gov/ cancertopics/types/breast
Lack of oestrogen receptor $\alpha(\mathrm{ER} \alpha)$ expression occurs in approximately one third of breast cancers, and is associated with poor prognosis, lack of responsiveness to anti-oestrogen therapeutics such as tamoxifen, and frequent resistance to chemotherapy. However, the underlying mechanism that commonly leads to loss of ER $\alpha$ expression remains largely unknown. Joyce Slingerland and colleagues now provide evidence that an important mechanism regulating ER $\alpha$ expression occurs at the posttranscriptional level in $\mathrm{ER} \alpha^{-}$breast cancers.

Previous studies have shown that ESR1 mRNA (which encodes ER $\alpha$ ) is detectable in many ER $\alpha^{-}$breast cancers. Consistently, using quantitative real-time PCR the authors showed that ESR1 mRNA was present at variable and overlapping levels in $200 \mathrm{ER} \alpha^{-}$and $50 \mathrm{ER} \alpha^{+}$primary breast cancers. Moreover, there was no significant difference in the mean ESR1 mRNA concentrations between the breast cancer subtypes, indicating that $\mathrm{ER} \alpha$ is regulated post-transcriptionally. The binding of oestrogen to ER $\alpha$ induces ubiquitylation and subsequent proteolysis of the activated receptor. The authors showed that stimulation of MCF-7 ER $\alpha^{+}$breast cancer cells with oestrogen together with growth factors reduced the levels of $\mathrm{ER} \alpha$, indicating that growth-factoractivated kinases might contribute to ligand-induced $\mathrm{ER} \alpha$ proteolysis. Indeed, the tyrosine kinase SRC shows cross-talk with ER $\alpha$ signalling, and treatment of MCF-7 cells with PP1, a Src family inhibitor, resulted in a dose-dependent accumulation of ER $\alpha$. Reciprocally, exogenous SRC expression reduced the half-life of $\mathrm{ER} \alpha$, and the induction of SRC in MCF-7 cells before oestrogen and growth factor stimulation further reduced the half-life of ER $\alpha$, indicating that SRC regulates the proteloysis of activated ER $\alpha$.

Activated ER $\alpha$ induces a transcriptional programme that regulates proliferation and development, driven by the transactivation of genes with oestrogen response elements (EREs). The authors showed that SRC induction and oestrogen stimulation synergistically increased the expression of ERE-driven genes, such as TFF1 and GREB1, suggesting that $\mathrm{ER} \alpha$ undergoes transcriptioncoupled degradation. Furthermore, increased SRC kinase activity was detected in $78 \%$ of ER $\alpha^{-}$but only $18 \%$ of $E R \alpha^{+}$primary breast cancers, suggesting that this could be a common mechanism by which ER $\alpha$ expression is lost in breast cancer. Consistently, in 101 breast cancer samples, ER $\alpha$ and SRC protein levels showed a statistically significant inverse correlation.

Therefore, $\mathrm{ER} \alpha^{-}$status does not necessarily indicate that $\mathrm{ER} \alpha$ is not expressed or that these cancers do not respond to oestrogen. Slingerland and colleagues propose that SRC might promote oncogenic proliferation by inducing transcription-coupled ER $\alpha$ degradation in at least a subset of $\mathrm{ER} \alpha^{-}$breast cancers. These data provide a rationale to investigate the therapeutic potential of SRC inhibitors with anti-oestrogen therapy in these patients.

Gemma Alderton

ORIGINAL RESEARCH PAPER Chu, l. et al. Src promotes estrogen-dependent estrogen receptor $\alpha$ proteolysis in human breast cancer. J. Clin. Invest. 12 July 2007 (doi: 10.1172/JCI21739)

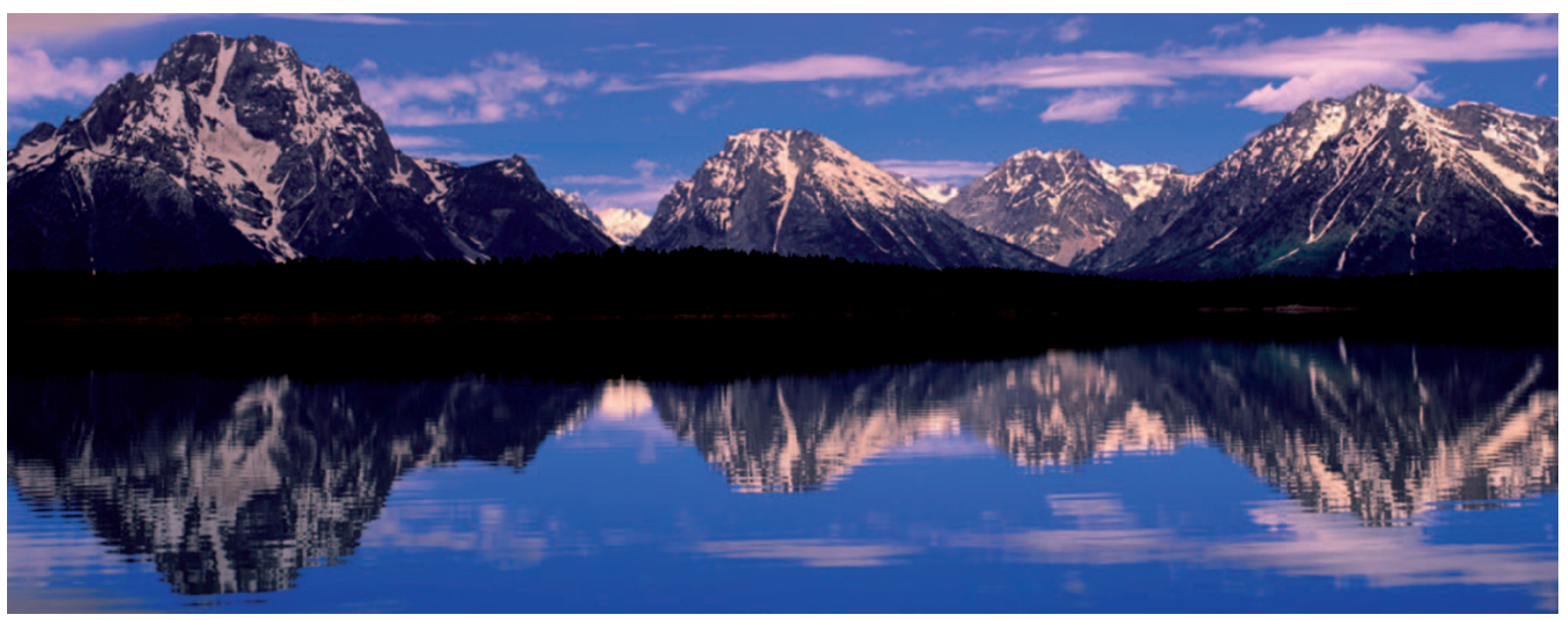

